\title{
CAMBRIDGE
}

Physics and Chance

Philosophical Issues in the

Foundations of Statistical

Mechanics

Lawrence Sklar

Statistical mechanics is one of the crucial fundamental theories of physics.

Lawrence Sklar, one of the pre-eminent philosophers of physics, offers a comprehensive, non-technical introduction to that theory and to attempts to understand its foundational elements.

Winner of the 1995 Lakatos Award E14.95 PB $0521558816 \quad 453$ pp.

\section{Philosophy and Technology}

\section{Edited by Roger Fellows}

This collection of essays examines the philosophical and cultural aspects of technology. The issues range from quantum technology to problems of technology and culture in a developing country.
E14.95
PB $0521558166 \quad 211$ pp.

Royal Institute of Philosophy Supplements 38

\section{Has Semantics}

Rested on a

\section{Mistake?}

\section{Howard Wettstein}

The essays in this book argue that Gottlob Frege's
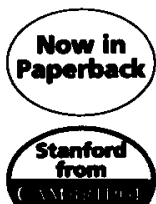

pivotal distinction between sense and reference, and his attendant philosophical views about language and thought, are unsatisfactory.

E11.95 PB $0804725276 \quad 246$ pp.

Stanford Series in Philosophy
The Problem of a Chinese Aesthetic

Haun Saussy

Exposing contemporary

literary theory to ancient

Chinese literature this book

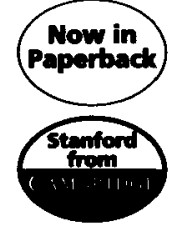

asks to what degree does the translation between languages and texts depend on allegory or translation within a single text or language?

f10.95 PB $0804725934 \quad 306$ pp.

Meridian: Crossing Aesthetics

\section{Knowledge and Belief in America}

Enlightenment Traditions and Modern Religious Thought

Edited by William M. Shea and Peter A. Huff

This volume unites the work of theologians, historians, literary critics, and philosophers to explore the interaction between Enlightenment ideals and American religion.

E37.50 HB $0521550114 \quad 372$ pp.

Woodrow Wilson Center Press

\section{Conceptual}

Foundations for

Multidisciplinary

\section{Thinking}

\section{Stephen Jay Kline}

This book provides a careful critique of our present approach of understanding and learning, putting the case for a multidisciplinary approach.

f30.00 HB $0804724091 \quad 356 \mathrm{pp}$.

Stanford University Press books are distributed outside North America by Cambridge University Press 


\section{CAMBRIDGE}

\section{Music and Conceptualization}

\section{Mark Debellis}

This book is a philosophical study of the relations between hearing and thinking about music. By applying the concepts and techniques of analytic philosophy the author explores the ways in which musical hearing may be described as nonconceptual, and how such mental representation contrasts with conceptual thought.

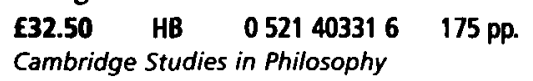

\section{Colours}

Their Nature and Representation

\section{Barry Maund}

The world as we experience it is full of colour. This book defends the radical thesis that no physical object has any of the colours we experience it as having. The author provides a unified account of colour that shows why we experience the illusion and why the illusion is not to be dispelled but welcomed.

$£ 35.00 \quad$ HB $0521472733 \quad 265$ pp.
Cambridge Studies in Philosophy

\section{Schopenhauer, Philosophy and the Arts}

\section{Edited by Dale Jacquette}

This collection of essays examines the unique theory which Schopenhauer developed to explain the life and work of the artist, and the influence which his aesthetic philosophy has had on subsequent artistic traditions in such diverse areas as music, painting, poetry, literature, and architecture.

$\begin{array}{llll}£ 35.00 & \text { HB } & 0521473888 & 323 \\ \text { pp. }\end{array}$
Landscape, Natural Beauty and the Arts Now in Beauty and the Arts Paperback and Ivan Gaskell

Landscape, Natural Beauty and the Arts, now in a paperback edition, offers probing studies of the complex structure of aesthetic responses to nature. Each chapter refines and expands the terms of discussion, and together they enrich the debate with insights from art history, literary criticism, geography and history. E13.95 PB 0521558549288 pp. Cambridge Studies in Philosophy and the Arts

\section{Image and Mind}

Film, Philosophy and Cognitive Science Gregory Currie

This is a book about the nature of film: about the nature of moving images, about the viewer's relation to film, and about the kinds of narrative that film is capable of presenting. It represents a very decisive break with the semiotic and psychoanalytic theories of film which have dominated discussion over the last twenty years.

\section{f37.50 HB $0521453569 \quad 325$ pp.}

\section{Supervenience}

New Essays

\section{Edited by Elias E. Savellos and Umit D. Yalcin}

Supervenience is one of the "hot discoveries' of recent analytic philosophy, and this collection of new essays on the topic represents a 'state of the art' examination of it and its application to major areas of philosophy.
$\mathbf{E 3 7 . 5 0}$ $333 \mathrm{pp}$. 


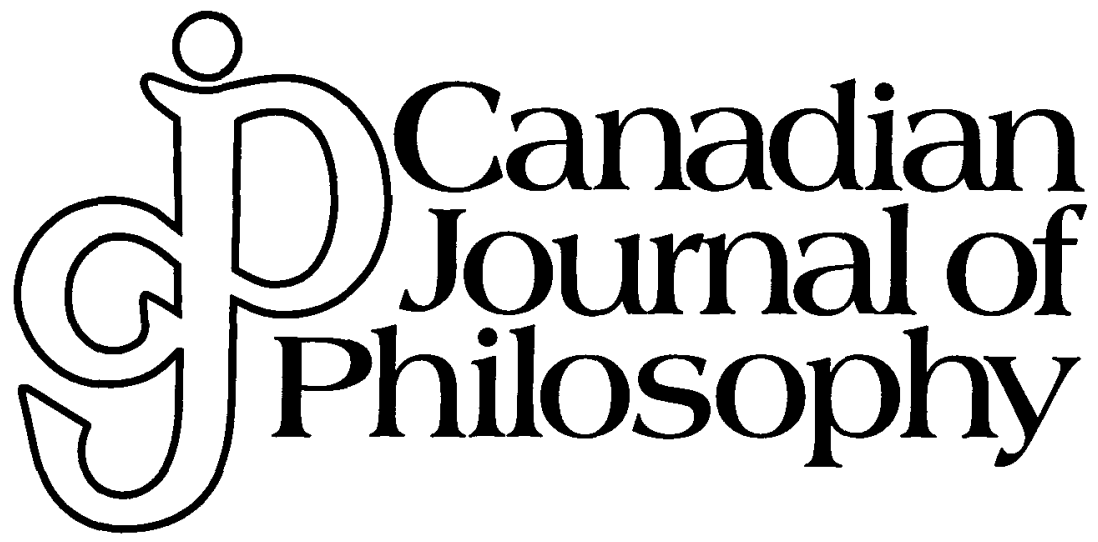

Recent and Forthcoming Articles

Scott Soames, "Beyond Singular Propositions?"

Dennis McKerlie, Critical Notice of Larry S. Temkin, Inequality

Richard Swinburne, "The Beginning of the Universe and of Time"

John Norton, "Are Thought Experiments Just What You Thought?"

Fred Dretske, "What Good is Consciousness?"

Joseph Heath, "Intergenerational Cooperation and Distributive Justice"

William Seager, "Dretske's Representational Theory of Consciousness"

\section{Supplementary Volumes}

A subscription to the Canadian Journal of Philosophy includes an annual Supplementary Volume of essays on a topic of current interest, e.g., Nationalism (1996), Meaning, Reference, and Truth (1997).

\section{Joint CJP/AJP Subscription}

The Canadian Journal of Philosophy offers a joint subscription with the Australasian Journal of Philosophy for $\$ 40$ (individual) and $\$ 25$ (student). The joint subscription includes four issues of each journal plus the Canadian Journal's annual Supplementary Volume.

\begin{tabular}{|c|c|c|c|c|}
\hline \multirow[b]{3}{*}{ Individual } & \multicolumn{2}{|c|}{ GP Subserimtion 1997} & \multicolumn{2}{|c|}{ 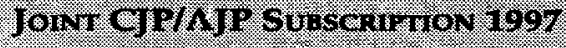 } \\
\hline & antion & eritida & $\begin{array}{l}\text { In } \\
\text { Canado }\end{array}$ & Omaride \\
\hline & $\$ 25.00$ & US $\$ 25.00$ & $\$ 40.00$ & US $\$ 40.00$ \\
\hline Student & $\$ 15.00$ & US\$15.00 & $\$ 25.00$ & US $\$ 25.00$ \\
\hline Institution & $\$ 50.00$ & US $\$ 50.00$ & $\mathrm{~N} / \mathrm{A}$ & $\mathrm{N} / \mathrm{A}$ \\
\hline & Canadian & G.S.T. & & \\
\hline
\end{tabular}

Send orders to: University of Calgary Press, 2500 University Drive N.W., Calgary, Alberta, Canada T2N 1N4 Telephóne: (403) 220-7578; Fax: (403) 282-0085 


\section{THE BRITISH JOURNAL OF}

\section{Aesthetics}

Founded in 1960, The British Journal of Aesthetics is highly regarded as an international forum for debate in aesthetics and the philosophy of art. Appearing quarterly - in January, April, July and October - it publishes thought-provoking articles on a broad range of topics from the nature of aesthetic judgement and the principles of art criticism to foundational issues concerning the visual arts, literature, music, photography, dance, film and architecture. A lively reviews section offers searching analyses of major new work in the field.

\section{A Selection of Articles in 1997}

Authentic Photographs, NIGEL WARBURTON

Ancient Chinese Aesthetics and Its Modernity, RUDOLF ARNHEIM

Defining Art Responsibility, JAMES O YOUNG

Two Kinds of Artistic Duplication, CHRISTOPHER JANAWAY

Meaning and the Art-Status of 'Music Alone', GRAHAM McFEE

On the Aesthetic Appreciation of Japanese Gardens, ALLEN CARLSON

The Marxist Theory of Art, GORDON GRAHAM

The Writer and Society: An Interpretation of Nausea, MARIE McGINN Irrecoverable Intentions and Literary Interpretation, BRIAN ROSEBURY

\section{Order Form for Volume 37 (4 issues) \\ a Institutions \$68/US\$124 I Individuals \$28/US\$48}

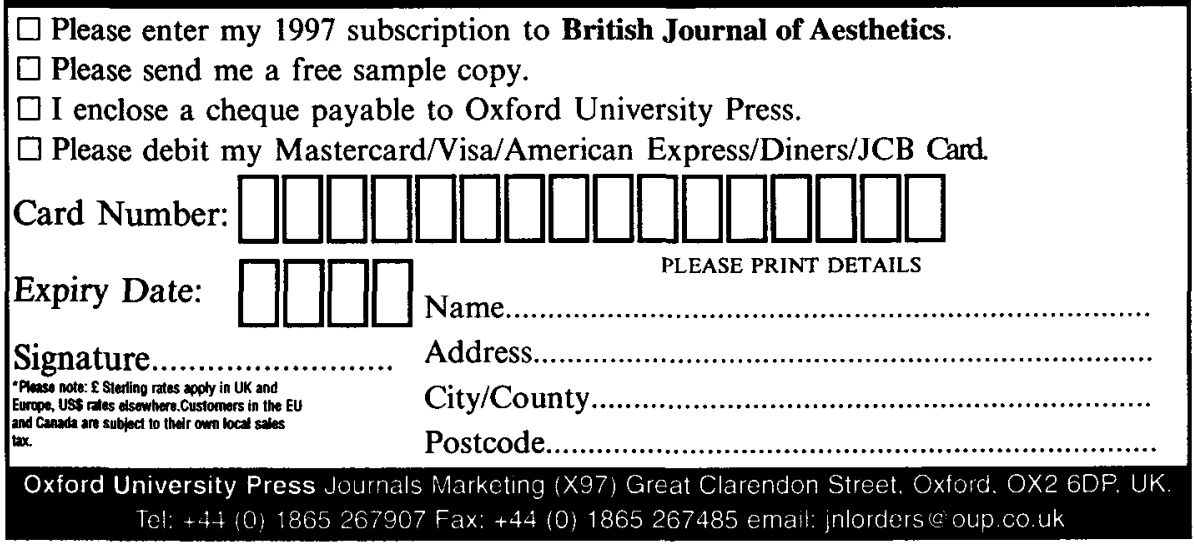




\section{CAMBRIDGE}

\section{Theories of Theories of Mind \\ Edited by Peter Carruthers and Peter K. Smith}

This book brings together contributions by a distinguished international team of philosophers, psychologists and primatologists, who offer a state of the art survey of the major topics in the theory-theory/simulationism debate within philosophy of mind, developmental psychology, the aetiology of autism and primatology.

$\begin{array}{llll}£ 40.00 & \text { HB } & 0521551102 & 406 \mathrm{pp} . \\ € 14.95 & \text { PB } & 0521559162 & \end{array}$

\section{Language, Thought and Consciousness}

An Essay in Philosophical Psychology Peter Carruthers

Do we think in natural language? Or is language only for communication? Much recent work in philosophy and cognitive science assumes the latter. In contrast, Peter Carruthers argues that much of human conscious thinking is conducted in the medium of natural language sentences.

$£ 35.00 \quad H B \quad 0521481589 \quad 308$ pp.

\section{Coming to Our Senses}

A Naturalistic Program for Semantic Localism

\section{Michael Devitt}

Michael Devitt takes up one of the most important difficulties that must be faced by philosophical semantics: namely, the threat posed by holism. This important study will be of particular interest to philosophers of language and mind.
$\mathbf{6} 40.00$
HB
052149543
$£ 14.95$
PB
0521498872
$350 \mathrm{pp}$.

Cambridge Studies in Philosophy

\section{Cartesian Psychology and Physical Minds}

Individualism and the Science of the Mind

\section{Robert A. Wilson}

Professor Wilson carefully examines the most influential arguments for individualism and identifies the main metaphysical assumptions underlying them. Because the topic is so central to the philosophy of mind, a discipline generating enormous research and debate at present, the book has implications for a very broad range of philosophical issues.

$\mathbf{E 3 7 . 5 0}$ HB $0521474027 \quad 287$ pp.
Cambridge Studies in Philosophy

\section{Object and Property}

\section{Arda Denkel}

Denkel argues that objects are nothing more than bundles of properties, and he tackles some central questions of ontology: how is an object distinct from others; how does it remain the same while it changes through time? A second contention is that properties are particular entities restricted to the objects they inhabit.

$\mathbf{1 3 5 . 0 0}$ HB $0521550106 \quad 275$ pp.
Cambridge Studies in Philosophy

\section{Subjects of Experience}

\section{E. J. Lowe}

E. J. Lowe demonstrates the inadequacy of physicalism, even in its mildest, nonreductionist guises, as a basis for a scientifically and philosophically acceptable account of human beings as subjects of experience, thought and action.

E32.50 HB $0521475031 \quad 215$ pp. Cambridge Studies in Philosophy 


\section{CAMBRIDGE}

\section{Liberation from Self}

A Theory of Personal Autonomy

\section{Bernard Berofsky}

Professor Berofsky claims that the idea of autonomy originating in the self is a seductive but ultimately illusory one. The only serious way of approaching the subject is to pay due attention to psychology, and to view autonomy as the liberation from the disabling effects of physiological and psychological afflictions.

£37.50 HB $0521480450 \quad 277$ pp.

\section{Justice in Immigration}

\section{Warren A. Schwartz}

This book is the first interdisciplinary study of the fundamental normative issues underpinning immigration policy. A distinguished group of economists, political scientists, and philosophers offer a stimulating and provocative discussion of this complex topic.
E32.50
HB
052145288

Cambridge Studies in Philosophy and Law

\section{Justice and Christian Ethics}

\section{E. Clinton Gardner}

The theme of justice is of central importance both to Christian ethics and to moral thought today. Bringing to his discussion insights derived from theology and from secular law, Gardner's interpretation of justice in terms of covenant provides important resources for the renewal and transformation of justice in our society.

E30.00 HB $052149639 \times \quad 196 \mathrm{pp}$. New Studies in Christian Ethics 7

\section{Feuerbach and the Interpretation of Religion}

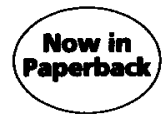

\section{Van A. Harvey}

Most scholars regard Feuerbach's criticism of Christianity as important because of its anticipation of the views of Nietzsche, Marx and Freud. Van Harvey argues that Feuerbach developed a much more interesting theory of religion than has been acknowledged hitherto.

\section{f13.95 PB $0521586305 \quad 329$ pp. \\ Cambridge Studies in Religion and Critical Thought 1}

\section{Kierkegaard as Religious Thinker}

\section{David J. Gouwens}

Gouwens explores Kierkegaard's religious and theological thought, focusing on human nature and Christianity. $\mathrm{He}$ discusses Kierkegaard's main concerns as a religious thinker, and his treatment of religion using the dialectic of 'becoming Christian'.

$\begin{array}{llll}\mathbf{f 3 5 . 0 0} & \text { HB } & 052146031 \times & 264 \mathrm{pp} . \\ \mathbf{f 1 2 . 9 5} & \text { PB } & 0521555515 & \end{array}$

\section{Ontological Arguments and} Belief in God

\section{Graham Oppy}

This book offers a comprehensive critical evaluation of ontological arguments for and against the existence of God. The author provides and analyses a critical taxonomy of those versions of the argument that have been advanced in recent philosophical literature, as well as of those historically important versions found in the work of St Anselm, Descartes, Leibniz, Hegel and others. E45.00 HB $0521481201 \quad 396 \mathrm{pp}$. 


\section{CAMBRIDGE}

\section{The Mask of Enlightenment Nietzsche's Zarathustra \\ Stanley Rosen \\ The Mask of Enlightenment is the most detailed textual and thematic study of one of Nietzsche's Thus Spake \\ Zarathustra. This book is sure to become the definitive study of Zarathustra, and will have a broad appeal to philosophers and students of modern philosophy, intellectual historians, political scientists, and literary theorists.

$\begin{array}{llrl}\text { E37.50 } & \text { HB } & 052149546 & 6 \\ \text { E13.95 } & \text { PB } & 052149889 & \text { pp. } \\ \text { Modern } & \text { European Philosophy }\end{array}$

\section{What is A Human Being?}

\section{A Heideggerian View}

\section{Frederick A. Olafson}

This book is at once an important application of Heidegger's thought to contemporary philosophical discussion, and a profound argument for a humanistic rather than scientific account of what it is to be a human being.

$\begin{array}{lllll}\text { E37.50 } & \text { HB } & 0521473950 & 272 \mathrm{pp} . \\ \text { E13.95 } & \text { PB } & 0521479371 & \\ \text { Modern European } & \text { Philosophy }\end{array}$

\section{Comte After Positivism}

\section{Robert C. Scharff}

This book provides the only detailed, systematic reconsideration of the neglected nineteenth-century positivist Auguste Comte currently available. Apart from offering an accurate account of what Comte actually wrote, the book argues that Comte's positivism has never had greater contemporary relevance than now.

$\begin{array}{llll}£ 37.50 & \text { HB } & 0521474884 & 241 \text { pp. }\end{array}$ Modern European Philosophy

\section{Reason in Action}

Essays in the Philosophy of Social Science Martin Hollis

In these essays, culled from twenty-five years' work, Martin Hollis argues that social action cannot be understood by viewing human beings as abstract individuals with preferences in search of satisfaction, nor by divorcing practical reason from questions of the rationality of norms, principles, practices and ends.

$\begin{array}{llll}\text { E37.50 } & \text { HB } & 052144263 X & 293 \mathrm{pp} . \\ \text { E13.95 } & \text { PB } & 0521447798 & \end{array}$

\section{Otto Neurath: Philosophy} Between Science and Politics Nancy Cartwright, Jordi Cat, Lola Fleck and Thomas E. Uebel

Four distinguished authors have been brought together to produce this elegant study of a much-neglected figure. Exploring Neurath's biographical background as well as his theory of science, this timely publication is a major contribution to our understanding of analytical philosophy.

$$
\text { f35.00 HB } 0521451744 \quad 304 \text { pp. }
$$$$
\text { Ideas in Context } 38
$$

\section{The Frankenstein Syndrome}

\section{Bernard E. Rollin}

This book is a philosophically sophisticated and scientifically wellinformed discussion of the moral and social issues raised by genetically engineering animals, a powerful technology which has major implications for society.

$\begin{array}{llll}\mathbf{E} 35.00 & \text { HB } & 052147230 X & 255 \mathrm{pp} . \\ \text { E12.95 } & \text { PB } & 0521478073 & \end{array}$

Cambridge Studies in Philosophy and Public Policy 


\section{CAMBRIDGE}

\section{The Cambridge Dictionary of Philosophy \\ Edited by Robert Audi \\ This is the most authoritative and comprehensive one-volume dictionary of philosophy available in English. It contains over 4,000 entries, which range in length from 100 to 4,000 words. The Dictionary has been written by an international team of over 350 experts.

$\begin{array}{llll}\mathbf{6 5 5 . 0 0} & \text { HB } & 0521402247 & 912 \mathrm{pp} . \\ \mathbf{E 1 7 . 9 5} & \mathrm{PB} & 052148328 \times & \end{array}$

\section{The Cambridge Companion to Nietzsche}

\section{Edited by Bernd Magnus and Kathleen Higgins}

Friedrich Nietzsche was quite simply one of the most influential of modern thinkers. New readers will find this the most convenient, accessible guide to Nietzsche currently available. Advanced students will find a conspectus of recent developments in the interpretation of Nietzsche.

\section{E13.95 PB $\quad 0521367670 \quad 412$ pp.}

Cambridge Companions to Philosophy

\section{The Cambridge Companion to Husserl}

\section{Edited by Barry 5mith}

\section{and David Woodruff Smith}

The essays in this volume explore the full range of Husserl's work. There are treatments of his most important contributions to the philosophy of mind, epistemology, the philosophy of language, ontology, and mathematics. $\begin{array}{llll}\text { E13.95 PB } & 0521436168 & 525 \text { pp. }\end{array}$ Cambridge Companions to Philosophy
The Cambridge Companion to Spinoza

\section{Edited by Don Garrett}

The essays in this volume provide a clear and systematic exegesis of Spinoza's thought informed by the most recent scholarship. They cover his metaphysics, epistemology, philosophy of science, psychology, ethics, political theory, and theology, as well as his life and influence on later thinkers.

\section{£13.95 PB 0521398657}

Cambridge Companions to Philosophy

\section{Recollection and Experience} Plato's Theory of Learning and Its Successors

\section{Dominic Scott}

This book is concerned with theories about learning in the history of philosophy, especially ancient philosophy. It asks: does our knowledge arise just out of experience or do we have some innate knowledge as well? The book is original in comparing different theories over a wide period in a way that should be accessible to students of philosophy and classics as well as professionals.

f37.50 HB $0521474558 \quad 300$ pp.

\section{Aristotle's Modal Logic}

Essence and Entailment in the Organon Richard Patterson

Aristotle's Modal Logic presents a very new interpretation of Aristotle's logic by arguing that a proper understanding of the system depends on an appreciation of its connection to the metaphysics.

f37.50 HB $052145168 \times \quad 298$ pp. 


\section{Information for Authors}

Prospective authors should send their contributions, typed and doublespaced on quarto or A4 paper, to the Editor, Professor Anthony O'Hear, Royal Institute of Philosophy, 14 Gordon Square, London WC1H 0AG. They should retain a second copy for the purpose of checking proofs. When an article has been accepted for publication, the author is strongly encouraged to send a copy of the final version on computer disk (Apple Macintosh or IBM compatible PC) together with the hard copy typescript, giving details of the wordprocessing software used (Microsoft Word, Word or Word Perfect). However, the publisher reserves the right to typeset material by conventional means if an author's disk proves unsatisfactory. Authors should observe the conventions of the journal. The Editor may alter manuscripts wherever necessary to make them conform to the stylistic and bibliographical conventions of the journal. Single quotation marks should be used except where there is a quotation within another. The titles of books and journals should be underlined (i.e. to be printed in italics), as should foreign words. 'Titles of articles should be in single quotation marks.

Notes and references will be printed as footnotes and should be typed (double-spacing) on a separate sheet, numbered consecutively. They should be referred to in the text by superscripts. Citations should be as follows:

' H. B. Acton, The Philosophy of Punishment (London: Macmillan, 1969), 192-198.

${ }^{2}$ R. S. Downie and Elizabeth Telfer, 'Autonomy', Philosophy 46, No. 178 (October 1971), 295.

${ }^{3}$ Op. cit. note $1,101-112$.

${ }^{4}$ W. C. Wimsatt, 'Some Problems with the Concept of Feedback', Boston Studies in the Philosophy of Science, VIII, R. C. Buck and R. S. Cohen (eds.) (Dordrecht: D. Reidel, 1971), 242.

The return of contributions cannot be guaranteed unless they are accompanied by stamps, or in the case of contributions from abroad, by international coupons, to cover postage. A self-addressed envelope should also be enclosed.

Only corrections of printer's errors can be allowed in proofs. Authors are therefore asked to send any alterations or additions to Professor O'Hear as soon as possible after receiving his letter of acceptance.

Authors of articles, discussion papers and review articles will receive twenty-five offprints free of charge. Additional offprints can be ordered when proofs are returned by arrangement with the Institute.

Books for review should be sent to the Editor at the Institute and not to Cambridge University Press. Publishers are asked to note that nonphilosophical works are not reviewed in Philosophy.

Authors' corrected proofs should be sent to Professor O'Hear at Royal Institute of Philosophy, 14 Gordon Square, London, WC1H 0AG. All other correspondence should also be addressed to the Institute.

\section{CAMBRIDGE UNIVERSITY PRESS}

The Edinburgh Building, Cambridge CB2 2RU, United Kingdom

40 West 20th Street, New York, NY 10011-4211, USA

10 Stamford Road, Oakleigh, Melbourne 3166, Australia 


\section{Philosophy}

V(1.) ME: $72 \times(1280$ APRII 1997

Editorial: . Iagic Realism

T'ime and the Static Image - ReBBI I.F PoHIFVI

()n Wittgenstem on Cognitive Science - 1). PR(A) DF() T

Constructing a Hall of Reflection - STEPHEA . It l.H.A.I.

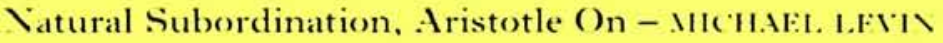

(jetting Around L anguage - RICHARI) MASON

Principle Ethics, Particularism and Another Possibility

$-S() R A \backslash$ RI:AI)E:R

\section{I) iscussion}

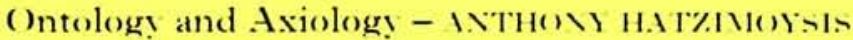

True and L'ltimate Responsibility - \. M. I. . AlHA)

The Intellectual Bias of Virtue Ethics - D.A. IFI. Pt INIAX

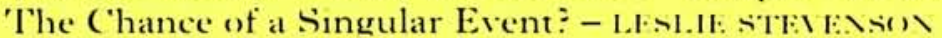

New Books

Reviews

Booknotes

Books Recerred

Notebook

1 The Royal Institute of Philosophỵ 1997

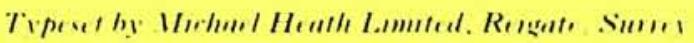

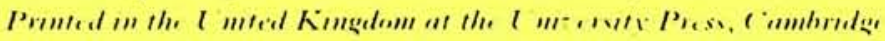

